\section{Salt Tolerance of Three Tree Species Differing in Native Habitats and Leaf Traits}

\author{
Nisa Leksungnoen ${ }^{\mathbf{a}}$ and Roger K. Kjelgren \\ Department of Plants, Soils, and Climate, Utah State University, 4820 Old \\ Main Hill, Logan, UT 84322-4820
}

Richard C. Beeson, Jr.

Institute of Food and Agricultural Sciences, Mid-Florida Research and Education Center, University of Florida, 2725 Binion Road, Apopka, FL 32703-8504

\section{Paul G. Johnson, Grant E. Cardon, and Austin Hawks Department of Plants, Soils, and Climate, Utah State University, 4820 Old Main Hill, Logan, UT 84322-4820}

Additional index words. bigleaf maple (Acer macrophyllum), canyon maple (Acer grandidentatum), electrical conductivity, Eucalyptus camaldulensis, reclaimed water, urban landscape irrigation

\begin{abstract}
We investigated if salt tolerance can be inferred from observable cues based on a woody species' native habitat and leaf traits. Such inferences could improve species selection for urban landscapes constrained by soils irrigated with reclaimed water. We studied the C3 tree species Acer grandidentatum Nutt. (canyon maple; xeric-non-saline habitat) that was hypothesized to have some degree of salt tolerance based on its semiarid but non-saline native habitat. We compared it with $A$. macrophyllum Pursh. (bigleaf maple) from mesic/riparian-non-saline habitats with much larger leaves and Eucalyptus camaldulensis Dehnh. (eucalyptus/red gum) from mesic-saline habitats with schlerophyllous evergreen leaves. Five levels of increasing salt concentrations (non-saline control to $12 \mathrm{dS} \cdot \mathrm{m}^{-1}$ ) were applied over 5 weeks to container-grown seedling trees in two separate studies, one in summer and the other in fall. We monitored leaf damage, gas exchange, and hydric behavior as measures of tree performance for 3 weeks after target salinity levels were reached. Eucalyptus was the most salt-tolerant among the species. At all elevated salinity levels, eucalyptus excluded salt from its root zone, unlike either maple species. Eucalyptus maintained intact, undamaged leaves with no effect on photosynthesis but with minor reductions in stomatal conductance $\left(g_{\mathrm{S}}\right)$. Conversely, bigleaf maple suffered increasing leaf damage, nearly defoliated at the highest levels, with decreasing gas exchange as salt concentration increased. Canyon maple leaves were not damaged and gas exchange was minimally affected at $3 \mathrm{dS} \cdot \mathrm{m}^{-1}$ but showed increasing damage at higher salt concentration. Salt-tolerant eucalyptus and riparian bigleaf maple framed canyon maple's moderate salt tolerance up to $3 \mathrm{dS} \cdot \mathrm{m}^{-1}$ that appears related to seasonal soil drying in its semiarid native habitat. These results highlight the potential to infer a degree of salt tolerance from either native habitat or known drought tolerance in selecting plant species for urban landscapes limited by soil salinity or brackish irrigation water. Observable cues such as xeri-morphic leaf traits may also provide visual evidence of salt tolerance.
\end{abstract}

Urban landscape plants are often grown well beyond the environmental boundaries of their native range, particularly in regard to precipitation. Irrigation mitigates water stress for plants from mesic habitats grown in arid region urban landscapes. Urban landscape plants are also often grown beyond the

Received for publication 2 June 2014. Accepted for publication 28 July 2014.

We thank the Ananthamahidol Foundation, the Utah Agricultural Experiment Station, and the Utah State University Center for Water Efficient Landscaping for supporting this experiment.

${ }^{1}$ To whom reprint requests should be addressed; e-mail nisa.leksungnoen@aggiemail.usu.edu. boundaries of salinity in their native habitats. Urban landscape irrigation with brackish reclaimed water is common in water-short U.S. cities as a result of the need to conserve high-quality potable water (Grieve, 2011; St. Hilaire et al., 2008). Reclaimed water is becoming an important resource in the arid to semiarid U.S. Intermountain West (IMW) as a result of rapid population growth and cyclic droughts (Jordan et al., 2001) that constrain water supply. Salt in reclaimed water used to irrigate landscape plants can potentially stress, damage, and reduce performance but is manageable (Niu and Cabrera, 2010). Salt concentrations in reclaimed water are readily monitored and generally at or below $3 \mathrm{dS} \cdot \mathrm{m}^{-1}$
(Tanji et al., 2008). Salt problems are managed by using species identified through empirical screening that are tolerant up to expected salinity in reclaimed water and maintaining a leaching fraction (Niu and Cabrera, 2010).

In the high desert IMW, low water landscaping with regionally native plants is promoted to conserve water, concurrent with use of reclaimed water (Meyer et al., 2009). Apart from the local halophytic, C4 members of the Chenopodiaceae, salt tolerance of other regional IMW native species found in non-saline soils is not definitively known without resource-intensive empirical studies (Zollinger et al., 2007). However, in semiarid regions, seasonal drying depletes soil water, concentrating salts that can influence evolution and distribution of non-halophytic species (Bui, 2013). In the mountainous IMW, low-elevation plant habitats have less precipitation and higher temperature, evaporation, and seasonal soil drying than higher elevation habitats (Meyer et al., 2009). Zollinger et al. (2007) studied salt dose-response of perennial wildflower species that included IMW species from hot, dry lower elevation habitats and cooler, wetter high-elevation habitats. The lower elevation species were more salt-tolerant than the higher elevation species, suggesting that salt tolerance can be inferred from aridity of a species' native habitat.

Inferring salt tolerance from a species' native habitat or drought tolerance has a basis in response mechanisms common to both stresses (Munns, 2002; Munns and Tester, 2008). Although mechanisms that isolate or exclude salt are unique to salt tolerance (Mimura et al., 2003), osmotic regulation is fundamental to both salt and drought stress response (Bartels and Sunkar, 2005). Plants can regulate internal osmotic concentration through common pathways of metabolite expression (Huang et al., 2012) to maintain water uptake and flow to leaves, in response to negative soil matric (drought) and soil osmotic (salt) potentials (Pastori and Foyer, 2002) to maintain gas exchange (Shannon, 1997). Additionally, salt and drought tolerance overlap in leaf traits. Water and salt stress both promote thicker (lower specific leaf area) and evergreen leaves (Abbruzzese et al., 2009; Wright et al., 2002) to conserve nutrients as well as other traits such as smaller leaves to reduce leaf heating (Wright et al., 2002).

Here we compare salt tolerance of two closely related maple species, canyon (Acer grandidentatum Nutt.) and bigleaf maple (A. macrophyllum Pursh.), the western members of the sugar maple (Acer saccharum) complex that spans North America (Desmarais, 1952; Godman et al., 1990). These maple species maintain a degree of shade tolerance and similar leaf shape (Guttay, 1976). Canyon maple is native to semiarid, midelevation woodlands found on seasonally dry soils in the IMW (Bsoul et al., 2007). Canyon maple's native habitat and small leaves ( 7 to $10 \mathrm{~cm}$ in diameter) point to drought tolerance favorable for use in regional low water landscapes (Richards et al., 2012). Bigleaf 
maple is native to riparian and partial understory habitats in the Northwest Pacific coastal lowlands and foothills (Minore and Zasada, 2010; Sarr et al., 2011) with much larger leaves, 20 in $30 \mathrm{~cm}$ in diameter, and rarely experiences seasonal soil drying compared with canyon maple. Our aim was to assess the degree that salt tolerance could be inferred from native habitat and leaf traits and so suggest de facto salt tolerance screening of other regionally native species for low water, salt-affected landscapes. To frame comparisons of the two maple species, we include Eucalyptus camaldulensis Dehnh. (red gum). E. camaldulensis is an Australian $\mathrm{C}_{3}$ tree-as are the maples - native to saline bottomlands with evergreen foliage and documented salt and drought tolerance (Cha-um and Kirdmanee, 2012; Grieve et al., 1999). As proxies for growth and appearance performance in landscapes, we focused on measures of leaf damage, gas exchange, and hydric behaviors that respond rapidly to salinity (Munns, 2002).

\section{Materials and Methods}

\section{Plant materials}

In Apr. 2009 and Mar. 2010, 1-year-old seedlings of the two Acer species were obtained bare root each year from local nurseries and transplanted in 3.8-L polyethylene containers (True\#1, Polytainer; Nursery Supplies, Inc., Orange, CA) filled with a commercial organic substrate (Sunshine mix \#1; SunGro Horticulture Canada Ltd.; sphagnum peatmoss amended with gypsum and dolomitic limestone). In July 2009 and Mar. 2010, eucalyptus seeds were germinated on germination paper (Seedburo Equipment Company). Two-month old eucalyptus seedlings $(\approx 0.5 \mathrm{~m}$ tall $)$ were transferred to 3.8 -L pots and grown as described for the Acer species. All pots were fertilized yearly in the spring with $20 \mathrm{~g}$ of a $12.7 \mathrm{~N}-7.6 \mathrm{P}-10.2 \mathrm{~K}$ controlled-release fertilizer (Osmocote 15-9-12; The Scotts Co., Marysville, $\mathrm{OH})$.

\section{Salinity treatments}

This experiment was first conducted in Fall 2009 (October to November) and repeated during Summer 2010 (June to August) in a climate-controlled greenhouse with temperature controlled at $25{ }^{\circ} \mathrm{C}$ from $0600 \mathrm{HR}$ to $1800 \mathrm{HR}$ and at $15^{\circ} \mathrm{C}$ from $1800 \mathrm{HR}$ to $0600 \mathrm{HR}$ with supplemental lighting from metal halide lamps. Salinity treatments were applied using a low-volume near-continuous gradient dosing system (Hawks et al., 2009) with $\mathrm{NaCl}$ and $\mathrm{CaCl}_{2} \cdot 2 \mathrm{H}_{2} \mathrm{O}$ mixed at a ratio of $151 \mathrm{~g}$ of $\mathrm{NaCl}: 809 \mathrm{~g}$ of $\mathrm{CaCl}_{2}$ in $1 \mathrm{~L}$ of water to reach five treatment levels: $0.4 \mathrm{dS} \cdot \mathrm{m}^{-1}$ (control treatment containing only nutrient solution) and $3,6,9$, and $12 \mathrm{dS} \cdot \mathrm{m}^{-1}$. This mixture was chosen to reflect $\mathrm{NaCl}$ as the common salt in reclaimed water (Wu et al., 2001) and to forestall potential calcium deficiencies (Carter and Grieve, 2006). In brief, irrigation water was mixed with a nutrient solution (Peter's Excel Multi-Purpose 21-5-20 water-soluble fertilizer at $100 \mathrm{ppm}$ nitrogen; Everris, Camarillo, CA) using an injection pump (Chemalizer Model CP33; Chemalizer Products, Largo, FL). Output was split going into the main nutrient solution delivery lateral or to a second pump. In the second pump, water containing the nutrient solution was injected with the desired salinity treatment. To control nutrient and treatment dosages, drip emitters of various flow rates (Rain Bird Corporation, Tucson, AZ) were combined to achieve the desired volume output.

Total output of all coupled emitters was designed to equal $45.4 \mathrm{~L} \cdot \mathrm{h}^{-1}$ at an injection pressure of $138 \mathrm{kPa}$ with an injection rate of 100:1 (nutrient solution: treatment solution). As an example, the control treatment was supplied only by a $45.4-\mathrm{L} \cdot \mathrm{h}^{-1}$ emitter attached to the nutrient line (Table 1). For the $3-\mathrm{dS} \cdot \mathrm{m}^{-1}$ treatment, both $7.6-\mathrm{L} \cdot \mathrm{h}^{-1}$ and $3.8-\mathrm{L} \cdot \mathrm{h}^{-1}$ emitters were plugged into the salinity treatment line, and $26.5-\mathrm{L} \cdot \mathrm{h}^{-1}$ and 7.6-L.h ${ }^{-1}$ emitters were connected to the nutrient line. The system was automated for 1-min irrigation periods at $0600 \mathrm{HR}$ and $1700 \mathrm{HR}$ daily to prevent water depletion in containers during the day and to ensure sufficient leaching and so preclude root zone salt accumulation. Leachate was collected from each container post-irrigation and stored in a sealed container. Electrical conductivity $\left(\mathrm{EC}_{\mathrm{e}}\right)$ of total collected leachate from each pot was measured weekly using a portable conductivity meter (Model Sension5; Hach Company, Loveland, CO) sampling. Containers of bare substrate without plants were maintained at each salinity treatment level to assess accuracy of target leachate $\mathrm{EC}_{\mathrm{e}}$ and indicate possible artifacts arising from substrate-salinity treatment interactions. We report on leachate collected from the summer study as representative of the accuracy of the delivery system in achieving target salinity levels.
Six plants per species were randomly assigned to each salinity treatment, which created a completely randomized experimental design. Salt concentration was increased in $3 \mathrm{dS} \cdot \mathrm{m}^{-1}$ increments until the highest concentration of $12 \mathrm{dS} \cdot \mathrm{m}^{-1}$ was obtained. In 2009 this increase was every $4 \mathrm{~d}$ from mid-October until early November but given rapid plant responses to salt before reaching to the target salt levels; thus, it was reduced to $2 \mathrm{~d}$ in 2010 . After reaching desired levels of salinity, plants were held at the target salinity level for 4 weeks.

\section{Measurements}

Leaf damage measurement. Leaf damage was measured only in 2010 as percent leaf area reduction relative to control plants starting immediately after salt treatments were applied. During the Fall 2009 study we observed no eucalyptus leaf damage at any salinity level, so we excluded eucalyptus from leaf damage measurements in 2010, where again eucalyptus showed no leaf damage. Before applying salt dosages, we harvested 25 leaves from a separate group of trees from each maple species and correlated leaf area (leaf area meter, Model 3100; LI-COR, Lincoln, NE) and leaf size (width $\times$ length) to develop a functional relationship to estimate reductions in leaf area from salinity. Because both maple species had set bud before each study, there was no change in leaf area from growth. Total leaf area for each tree was quantified at the end of the study using the same leaf area meter as a control on leaf area estimates from length and width measurements. Reduction in leaf area caused by necrosis from salt was calculated as percent change from initial leaf area.

Stomatal conductance and leaf water potential measurements. Plant water relations measurements were recorded weekly after target $\mathrm{EC}_{\mathrm{e}}$ levels were reached with six replications per treatment for each species. Stomatal conductance was measured once a week with a leaf porometer (SC-1 Decagon Devices, Pullman, WA) between 1100 HR and 1400 HR Mountain Daylight Time on a clear day of full sun on a single leaf from each plant (six replications per treatment). Leaf water potential $\left(\psi_{\text {leaf }}\right)$ was measured at midday concurrent with $g_{\mathrm{S}}$ during the final (third) week during the fall (2009) study and second and third weeks of the summer (2010) study to avoid confounding effects on leaf area. To further minimize confounding effects on leaf

Table 1. Salinity treatments output rates with drip emitter combinations and leachate electrical conductivity (EC $\mathrm{E}_{\mathrm{e}}$ collection in 2010

\begin{tabular}{|c|c|c|c|c|c|c|}
\hline \multirow[b]{2}{*}{ Treatment $^{\mathrm{z}}\left(\mathrm{dS} \cdot \mathrm{m}^{-1}\right)$} & \multicolumn{2}{|c|}{ Emitter combination $^{\mathrm{y}}$} & \multicolumn{4}{|c|}{ Leachate $\mathrm{EC}_{\mathrm{e}}\left(\mathrm{dS} \cdot \mathrm{m}^{-1}\right) \pm \mathrm{SE}^{\mathrm{x}}$} \\
\hline & Nutrient $\left(\mathrm{L} \cdot \mathrm{h}^{-1}\right)$ & Treatment $\left(\mathrm{L} \cdot \mathrm{h}^{-1}\right)$ & No plant & Eucalyptus & Bigleaf maple & Canyon maple \\
\hline Control (0.4) & 45.4 & 0 & $0.39 \pm 0.03 \mathrm{a}^{\mathrm{w}}$ & $0.39 \pm 0.05 \mathrm{a}$ & $0.39 \pm 0.03 \mathrm{a}$ & $0.33 \pm 0.02 \mathrm{a}$ \\
\hline 3 & $26.5+7.6$ & $7.6+3.8$ & $3.92 \pm 0.22 \mathrm{a}$ & $5.26 \pm 0.43 \mathrm{~b}$ & $3.44 \pm 0.17 \mathrm{a}$ & $3.28 \pm 0.16 \mathrm{a}$ \\
\hline 6 & $18.9+3.8$ & $18.9+3.8$ & $6.69 \pm 0.41 \mathrm{a}$ & $10.48 \pm 0.38 \mathrm{~b}$ & $6.69 \pm 0.34 \mathrm{a}$ & $5.70 \pm 0.44 \mathrm{a}$ \\
\hline 9 & $7.6+3.8$ & $26.5+7.6$ & $8.91 \pm 0.12 \mathrm{a}$ & $12.42 \pm 0.46 \mathrm{~b}$ & $8.95 \pm 0.43 \mathrm{a}$ & $9.14 \pm 0.34 \mathrm{a}$ \\
\hline 12 & 0 & 45.4 & $11.74 \pm 0.14 \mathrm{a}$ & $15.56 \pm 0.57 \mathrm{~b}$ & $12.00 \pm 0.43 \mathrm{a}$ & $11.77 \pm 0.32 \mathrm{a}$ \\
\hline
\end{tabular}

zTarget salinity of applied water.

${ }^{y}$ Emitter combination between nutrient solution and salinity treatment solution to obtain final target rate of $45.4 \mathrm{~L} \cdot \mathrm{h}^{-1}$ of five different salinity levels.

${ }^{\mathrm{x}}$ Leachate collected from each pot $(\mathrm{n}=6$ plants) with $\mathrm{sE}$, averaged over study period (5 weeks).

${ }^{\text {w}}$ Values followed by the same letter in rows are not difference at $P \leq 0.05$. 
area, an expanded mature but smaller leaf low in the crown from each plant was cut at the petiole base and immediately inserted into the pressure chamber (Model 3005HGPL; Soil Moisture Equipment Corp., Santa Barbara, CA). Compressed nitrogen gas was used to apply pressure at a rate of $30 \mathrm{kPa}(0.3$ $\mathrm{MPa} / \mathrm{sec}$ until the balance pressure was obtained. Leaves excised for water potential measurement were excluded from leaf area calculations.

Photosynthesis measurement. Net photosynthesis (A) was measured using a portable photosynthesis system with a chlorophyll fluorescence attachment (Model LI-6400; LI-COR) after target $\mathrm{EC}_{\mathrm{e}}$ levels were obtained with three replications per salinity treatment for each species. An expanded mature intact leaf was placed into the fluorescence chamber. The instrument was set with the air flow rate at $500 \mathrm{mmol} \cdot \mathrm{s}^{-1}, \mathrm{CO}_{2}$ at $400 \mu \mathrm{mol} \cdot \mathrm{mol}^{-1}$, and light at 1000 to 1200 $\mu \mathrm{mol} \cdot \mathrm{m}^{-2} \cdot \mathrm{s}^{-1}$ with $10 \%$ blue light. Data were manually logged after photosynthesis, $\mathrm{CO}_{2}$, $\mathrm{H}_{2} \mathrm{O}$, and fluorescence were stable. All salinity levels were measured in the fall study, but as a result of equipment limitations, only 0,6 , and $12 \mathrm{dS} \cdot \mathrm{m}^{-1}$ were measured in the summer study.

\section{Analysis}

The experiment was a completely randomized two-level factorial design. Species (three levels) and salinity treatments (five levels) with six replications for each treatment combination were used in the leachate $\mathrm{EC}_{\mathrm{e}}, g_{\mathrm{S}}$, and $\psi_{\text {leaf }}$ measurements with three replications used in A measurement. Treatment effects, species differences, and treatments $\times$ species interactions were determined by analysis of variance according to the GLM procedure of SAS (Version 9.0; SAS Institute, Cary, NC). Leaf damage was analyzed based on repeated measurement using MIXED procedure of SAS. Weeks were treated as a repeated measurement with autoregressive type 1 model-ar(1) to test mean differences by recognition that more proximate observations are more correlated than those more distant. Mean separation differences were tested with least significant difference test at a probability level of 0.05 .

We assessed hydric behavior by plotting normalized $g_{\mathrm{S}}$ to water potential to assess the degree of stomatal regulation over internal water status to maintain water flow from the saline root zone to the leaf after the procedure described by Kjelgren et al. (2009). We normalized by dividing $g_{\mathrm{S}}$ and $\psi_{\text {leaf }}$ at each salinity level by control $g_{S}$ and $\psi_{\text {leaf }}$ to eliminate day-to-day variations in each variable (control was set equal to 1 ). Normalized $g_{\mathrm{S}}<1$ indicated stomatal closure, and $\psi_{\text {leaf }}>$ 1 indicated greater (more negative) change in xylem water potential. Based on availability of $\psi_{\text {leaf }}$ data, only the last data measurements were used in 2009, whereas in 2010, final measurements and data were collected the final 2 weeks. SE each for normalized $g_{\mathrm{S}}$ and $\psi_{\text {leaf }}$ was derived from the variance at each salinity level divided by the variance of the control.

\section{Results and Discussion}

Monitoring salt delivery concentrations. Eucalyptus showed a key salt tolerance mechanism by excluding salts from uptake, whereas the two maple species did not (Table 1). The salt delivery system was accurate, because leachate $\mathrm{EC}_{\mathrm{e}}$ collected from bare soil pots without plants closely tracked target levels. Leachate from the substrate of the two maples also tracked target levels, indicating that they did not detectably exclude salts from root uptake and likely moved salts to leaves that would concentrate from transpiration (Munns, 2002). Salt-sensitive plants accumulate more salts in leaves than tolerant species (Wu et al., 2001), and Valdez-Aguilar et al. (2011) showed salt accumulation in leaves of several sensitive woody landscape species. By contrast, eucalyptus appeared to exclude enough salt from uptake by roots to consistently increase substrate leachate $\mathrm{EC}_{\mathrm{e}}$ in excess of the target conductivity at every salt level except the no-salt control, a salt tolerance mechanism previously reported (Nasim et al., 2009). Leachate $\mathrm{EC}_{\mathrm{e}}$ ranged from $\approx 50 \%$ more at the 3 - and $6-\mathrm{dS} \cdot \mathrm{m}^{-1}$ treatments to $30 \%$ more at $12 \mathrm{dS} \cdot \mathrm{m}^{-1}$ than target levels.

Leaf damage. Canyon maple was more resistant to leaf damage than bigleaf maple but more affected at higher salt concentration than eucalyptus, a pattern observed in 2009 and measured in 2010 (Figs. 1 and 2). Eucalyptus leaf area was unaffected by any salinity treatment either year with no signs of damage on any leaf at any salinity level in both studies. Eucalyptus is reported to tolerate and grow at salt levels up to $20 \mathrm{dS} \cdot \mathrm{m}^{-1}$ (Grieve et al., 1999), where the evergreen, schlerophyllous leaves contribute to tolerance in its native wet, saline habitats in Australia (Farrell et al., 1996). By comparison, both maple species exhibited leaf damage and margin burn at different levels of salinity.

Bigleaf maple leaves were the reciprocal of eucalyptus, showing damage with increasing $\mathrm{EC}_{\mathrm{e}}$ above the control and near defoliation at the highest salt levels. Bigleaf maple's native cool, moist habitat allows for its eponymous large leaves and a high transpiration rate under favorable conditions (McCulloh et al., 2010). In this study, initially high transpiration rates and so ostensible salt uptake resulted in immediate visible leaf damage at $12 \mathrm{dS} \cdot \mathrm{m}^{-1}, 50 \%$ leaf area loss by the third week, and near defoliation by the end of the study. Bigleaf maple did not look better at the intermediate salt levels with $50 \%$ to $75 \%$ leaf area loss by the end of the study and substantial leaf bleaching. Although bigleaf maple at $3 \mathrm{dS} \cdot \mathrm{m}^{-1}$ did not show leaf bleaching by the end of the study, leaf damage from margin burn was variable but still substantial.

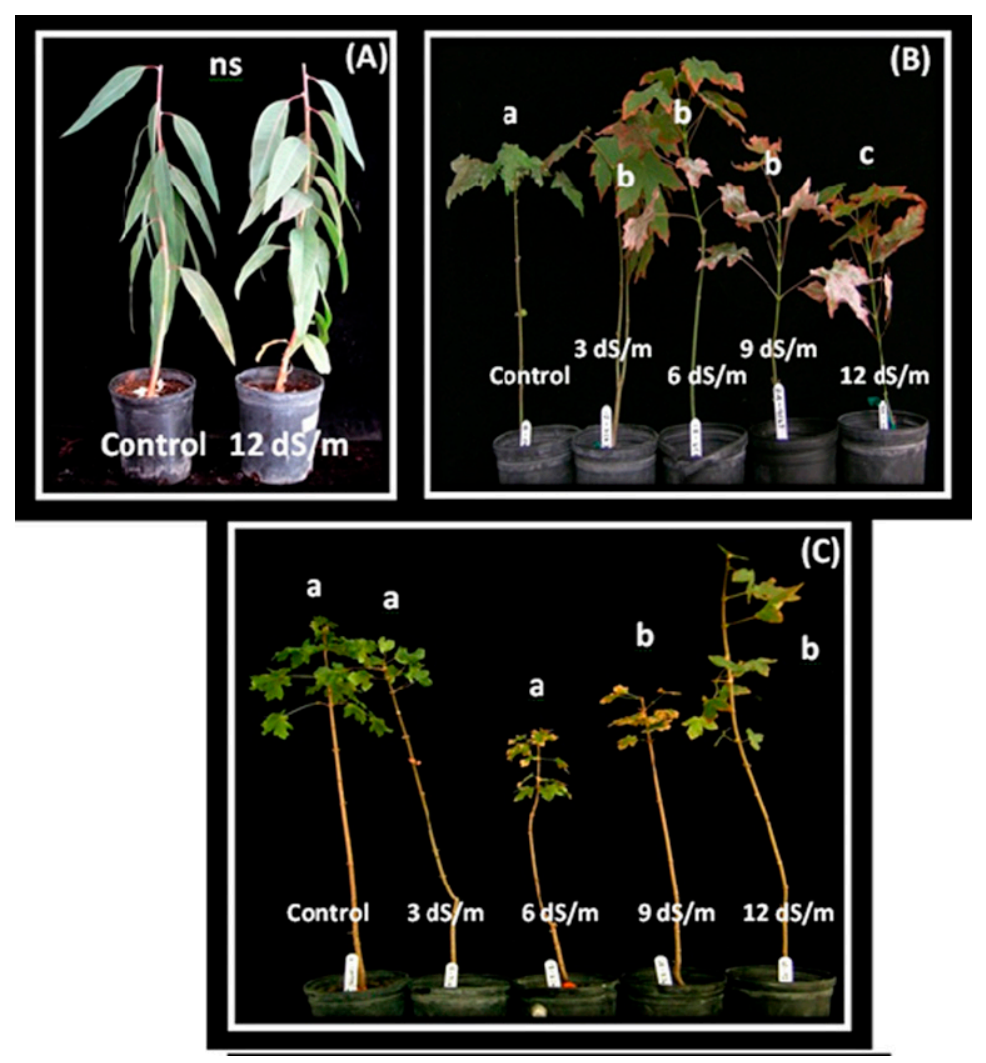

Fig. 1. Leaf area damage in 2010 of (A) Eucalyptus camaldulensis Dehnh. (eucalyptus), (B) Acer macrophyllum Pursh. (bigleaf maple), and (C) A. grandidentatum Nutt.(canyon maple) under levels of elevated salinity. The same letters are not significantly different at $P \leq 0.05$ for leaf damage in each species at the end of the Summer 2010 study. 


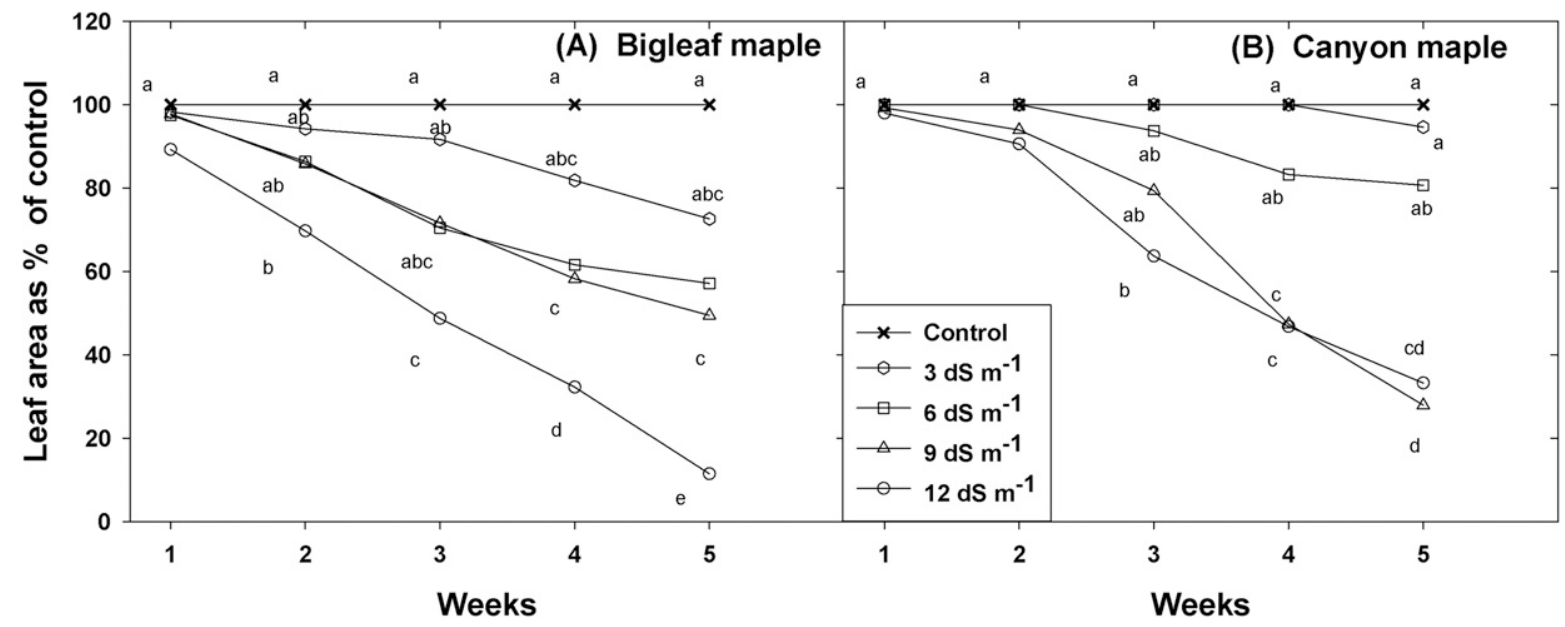

Fig. 2. Percent green leaf area over a 5-week study period under five levels of elevated salinity in 2010 (midsummer) of (A) Acer macrophyllum Pursh. (bigleaf maple) and (B) A. grandidentatum Nutt. (canyon maple). The same letters are not significantly different at $P \leq 0.05$ of for each week in both species using repeated measurement analysis.

Leaf area loss in canyon maple appeared later and was less severe than bigleaf maple (Fig. 2B), emerging at the two highest levels after 2 weeks. Trees at the $6 \mathrm{dS} \cdot \mathrm{m}^{-1}$ showed only minimal margin burn at the end of the study, and there was no leaf bleaching at any of the three highest salt levels. Notably, leaf appearance of canyon maple at $3 \mathrm{dS} \cdot \mathrm{m}^{-1}$ showed no damage and was not different from the control throughout the study. This salt level is somewhat higher than $1.7 \mathrm{dS} \cdot \mathrm{m}^{-1}$ associated with leaf damage in canyon maple irrigated with municipal water (Hatter and Morgan, 1992). Compared with bigleaf maple, canyon maple's smaller leaves may have mitigated to a degree salt accumulation: smaller leaves would dissipate radiation more effectively, stay cooler, and have a lower transpiration rate (Bsoul et al., 2007), so ostensible salt uptake and accumulation would likely be slower.

Physiological responses to salinity stress. Eucalyptus and bigleaf maple also flanked canyon maple in terms of gas exchange and water relations. Eucalyptus camaldulensis is commonly used in agroforestry as a result of its wide adaptability to salt (Grieve et al., 1999), expressed as robust gas exchange (Cha-Um and Kirdmanee, 2010), and ability to osmoregulate to maintain water uptake (White et al., 2000). Such was the case with eucalyptus in this study: $g_{\mathrm{S}}$ and $A$ were consistently two to three times greater and $\psi_{\text {leaf }}$ more negative than that of both maple species both years (Fig. 3). The difference was greater in summer, possibly as a result of longer days; except at the highest salt concentration, $g_{\mathrm{S}}$ declined and $\psi_{\text {leaf }}$ moderated compared with the fall study. Some salt ions are taken up in eucalyptus xylem stream and so accumulate in leaves (Grieve and Shannon, 1999). Our results indicate that any accumulate was not enough to affect $\mathrm{A}$ that was the same in both studies, suggesting that reduced $g_{\mathrm{S}}$ may have been an osmotic effect (Munns and Tester, 2008).

Despite no apparent root salt exclusion, canyon maple gas exchange and $\psi_{\text {leaf }}$ showed greater resistance to salt than that of bigleaf

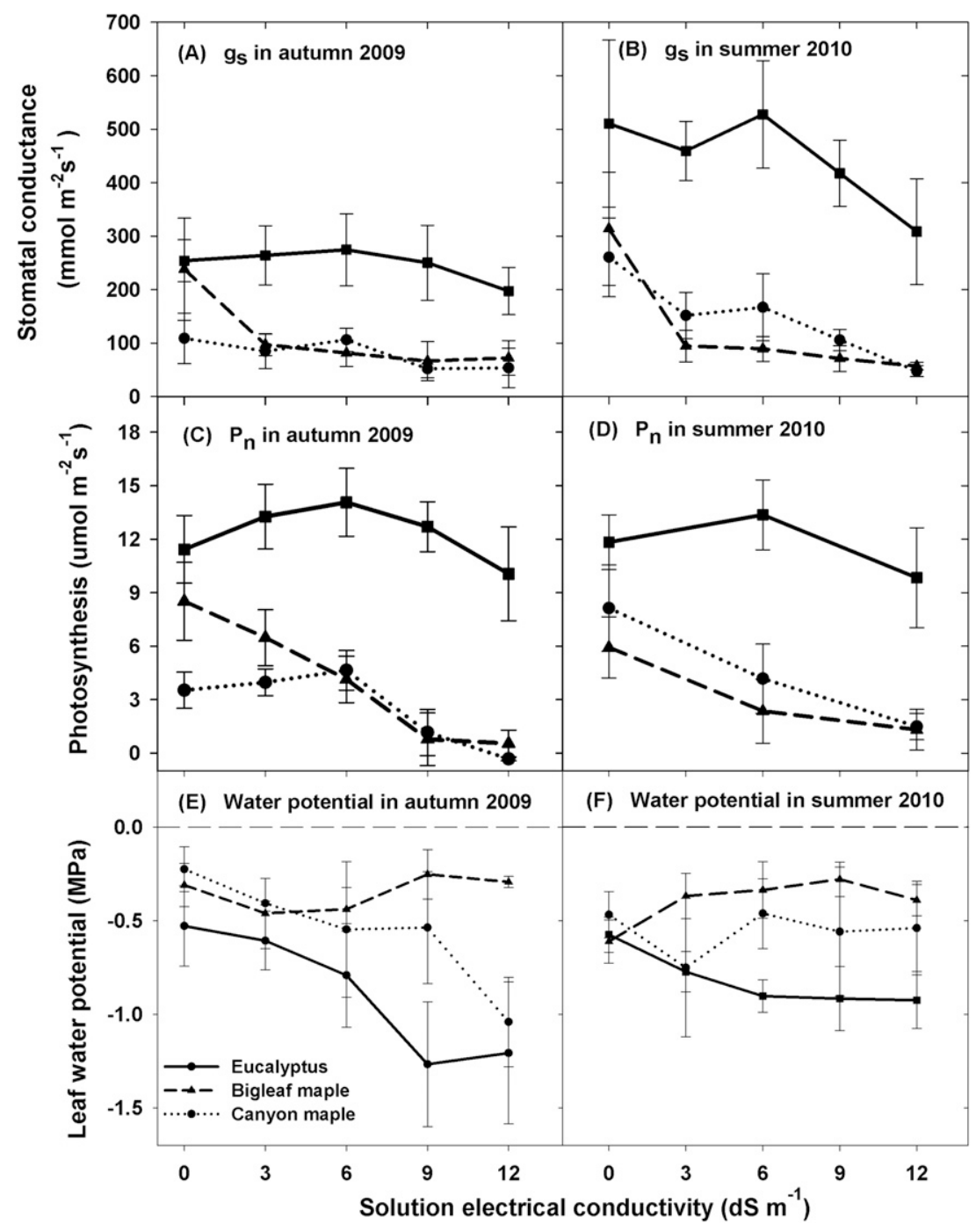

Fig. 3. Physiological measurements under different salinity treatments of Eucalyptus camaldulensis Dehnh. (eucalyptus), Acer macrophyllum Pursh. (bigleaf maple), and A. grandidentatum Nutt. (canyon maple) in 2009 and 2010 at the end of each 5-week study period for the summer and fall studies, including stomatal conductance $\left(g_{\mathrm{S}}\right)(\mathbf{A}-\mathbf{B})$, photosynthesis $(\mathbf{C}-\mathbf{D})$, and leaf water potential $(\mathbf{E}-\mathbf{F})$.

maple. Bigleaf maple's complete gas exchange shutdown at all salt levels suggests an immediate osmotic effect on $g_{\mathrm{S}}$ and transpiration (Abbruzzese et al., 2009), helping to moderate $\psi_{\text {leaf }}$. Concurrently, salt appeared to directly damage chloroplasts 
(Munns and Tester, 2008) and reduce A at all salt levels. Canyon maple performed better: in fall, under shorter days and less radiance, A was constant between 3 and $5 \mu \mathrm{mol} \cdot \mathrm{m}^{-2} \cdot \mathrm{s}^{-1}$ up to $6 \mathrm{dS} \cdot \mathrm{m}^{-1}$ and in summer maintained a similar rate also up to $6 \mathrm{dS} \cdot \mathrm{m}^{-1}$, although declining by half from the control. In both studies $g_{\mathrm{S}}$ was more affected than A at 3 $\mathrm{dS} \cdot \mathrm{m}^{-1}$ and above, suggesting a more immediate, pronounced osmotic effect (Munns, 2002; Munns and Tester, 2008). A rapid osmotic effect might affect growth rather than appearance, as Valdez-Aguilar et al. (2011) observed in Hibiscus syriacus.

Canyon maple salt tolerance relative to control plants is more clearly illustrated in evaluating the $\mathrm{EC}_{\mathrm{e}}$ that caused a $50 \%$ reduction in $g_{\mathrm{S}}\left(g_{\mathrm{S} 50}\right)$ and photosynthesis $\left(A_{50}\right)$. Over both years $(P \leq 0.0001)$, both $g_{\mathrm{S} 50}$ and $A_{50}$ were greatest in eucalyptus and least in bigleaf maple, respectively, $14.4 \mathrm{dS} \cdot \mathrm{m}^{-1}$ and $15.0 \mathrm{dS} \cdot \mathrm{m}^{-1}$ compared with $3.6 \mathrm{dS} \cdot \mathrm{m}^{-1}$ and $4.7 \mathrm{dS} \cdot \mathrm{m}^{-1}$. Canyon maple $g_{\mathrm{S} 50}$ and $A_{50}$ were intermediate at $9.8 \mathrm{dS} \cdot \mathrm{m}^{-1}$ and $9.1 \mathrm{dS} \cdot \mathrm{m}^{-1}$, although the differences between the Acer species was not large $(P=0.109)$.

Hydric behavior. Finally, canyon maple hydric behavior that integrated $g_{\mathrm{S}}$ and $\psi_{\text {leaf }}$ was intermediate between eucalyptus and bigleaf maple (Fig. 4). Hydric behavior describes the extent that internal water potential varies with soil and atmospheric water deficits. Anisohydric response to water deficits allows $\psi_{\text {leaf }}$ to vary while keeping stomata more open and $g_{\mathrm{S}}$ relatively constant, a competitive advantage under brief, less intense deficits to exploit root zone water and so sustains A. By contrast, isohydric responses allow $g_{\mathrm{S}}$ to vary with soil and atmospheric deficits to moderate $\psi_{\text {leaf }}$ and minimize xylem cavitation risk and depletion of root zone water (Schultz, 2003; Tardieu and Simmoneau, 1998), but at the cost of stomatal limits on A. Previously the analysis in Figure 4 was applied to soil and atmospheric deficits (Kjelgren et al., 2009); here hydric behavior in response to salt stress can be similarly described but with different meaning.

Eucalyptus showed ostensible anisohydric behavior but more pronounced in fall than midsummer. Eucalyptus $\psi_{\text {leaf }}$ was two to three times less (more negative) than control as salt concentration increased, maintaining water flow to leaves from osmotically droughty substrate, likely as a result of osmoregulation. The corresponding $g_{\mathrm{S}}$ decreased to $50 \%$ to $65 \%$ of control, possibly as a result of osmotic effects at high salt levels (Munns and Tester, 2008), but not enough stomatal closure to affect photosynthetic apparatus and detectably reduce A (Munns, 2002; Niu and Cabrera, 2010). By contrast, bigleaf maple appeared to show extreme isohydric behavior, exercising no control over $\psi_{\text {leaf }}$ to maintain gas exchange: $g_{\mathrm{S}}$ fell to $40 \%$ of control levels in fall and $20 \%$ in summer, whereas $\psi_{\text {leaf }}$ remained nearly constant at all salt concentrations. Ostensible isohydric moderation of $\psi_{\text {leaf }}$ was likely less a coordinated, adaptive stress response than a byproduct of stress shock: reduced whole-plant transpiration (low $g_{\mathrm{S}}$ and loss of transpiring leaf area

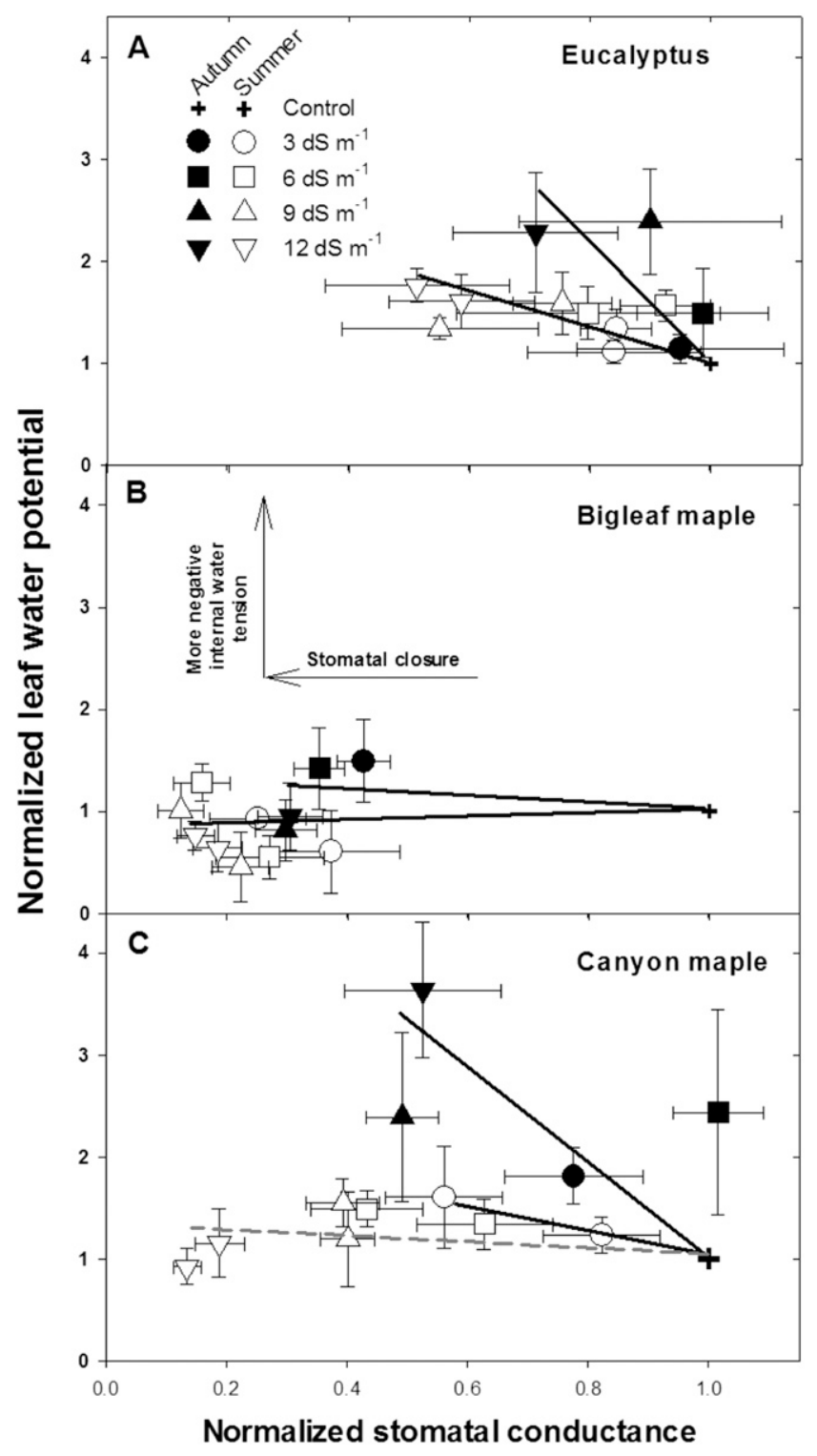

Fig. 4. Response of normalized water potential to stomatal conductance (salinity treatment values for each variable divided by control values) for (A) Eucalyptus camaldulensis Dehnh. (eucalyptus), (B) Acer macrophyllum Pursh. (bigleaf maple), and (C) A. grandidentatum Nutt. (canyon maple) plus SE of normalized variance. Data plotted with trend lines separately for the Fall 2009 (data collected from third/final week only) and Summer 2010 (data from second and third/final weeks) studies, except for canyon maple in 2010 where the response line for responses exhibiting anisophydric behavior at 3 and $6 \mathrm{dS} \cdot \mathrm{m}^{-1}$ were plotted separately from the isohydric responses at high salt concentration.

from necrosis) combined with no detectable osmoregulation.

Canyon maple showed mixed ostensible hydric behavior: anisohydric in fall as $g_{\mathrm{S}}$ declined to $\approx 50 \%$ at the highest dosage, while allowing 4-fold more negative $\psi_{\text {leaf }}$ than the control, although absolute values were lower than in summer. During the last 2 weeks of the summer study, canyon maple maintained an anisohydric response up to 3 to $6 \mathrm{dS} \cdot \mathrm{m}^{-1}$, where $g_{\mathrm{S}}$ fell to $55 \%$ to $80 \%$ of control while maintaining a $\psi_{\text {leaf }}$ up to 1.5 -fold more negative. This suggests some upward water flow and carbon uptake (Fig. 3 ). At higher dosages, canyon maple patterned an isohydric response, where leaf area loss and reduced $g_{S}$ likely moderated $\psi_{\text {leaf }}$. Less pronounced hydric responses in summer were possibly the result of more extreme aboveground conditions (Niu and Cabrera, 2010): some combination of greater midday insolation inducing stomatal sensitivity to vapor pressure deficits interacting with osmotic effects from longer days with more salt accumulation in leaves. Similar seasonal responses were reported by Niu et al. (2010) and Zollinger et al. (2007).

\section{Conclusion}

We infer that the canyon maple salt tolerance demonstrated here arose from its IMW semiarid woodland habitat characterized by seasonal soil drying. Canyon maple's tolerance is in contrast to bigleaf maple's salt intolerance arising from its non-saline, 
riparian habitat where seasonal soil drying is rare enough to not induce any level of salt tolerance. Eucalyptus from a wet-saline habitat then frames canyon maple with a much higher level of salt tolerance in leaf appearance, gas exchange, and hydric behavior. These results suggest canyon maple can be used in IMW urban landscapes irrigated with reclaimed water with ECs classified as moderate $\left(3 \mathrm{dS} \cdot \mathrm{m}^{-1}\right)$ or less (Tanji et al., 2008). Such use assumes sufficient leaching fraction and minimal foliar interception of overhead irrigation water, because salt on leaves is more damaging than salt-affected soil in hot, high evaporative demand climates such as the IMW (Jordan et al., 2001). Unclear from this study is how canyon maple leaf area expansion and shoot elongation would fare under moderate soil salinity. Stomatal responses presented here and growth responses reported elsewhere (Hatter and Morgan, 1992) suggest that canyon maple may maintain acceptable appearance but have limited growth (Valdez-Aguilar et al., 2011).

At larger perspective, these results illuminate a possible line of inquiry into de facto salt tolerance screening based on inferences from observable ecological cues. Site water balance (precipitation minus evaporation) and xeri-morphic leaf traits (small, glaucous, vertical, thick, evergreen among other traits) commonly describe plant drought-tolerant traits that may also reflect salt tolerance (Bartels and Sunkar, 2005; Farooq and Azam, 2001). This reflection points to droughty habitats and xeri-morphic traits as reasonable proxies for seasonal salt accumulation (Bui, 2013) and leaf responses (Abbruzzese et al., 2009; Maricle et al., 2007) that would infer salt tolerance. For example, in addition to canyon maple, there are a number of regionally native IMW species valuable for low water landscapes that may also have moderate salt tolerance based on their semiarid woodland or shrub-steppe habitats and xeri-morphic leaf traits. These include Quercus gambellii, Fraxinus anomala, Cercocarpus ledifolius, Cercocarpus intricatus, Ephedra viridis, and Purshia mexicana (Mee et al., 2003). Empirical screening of these species for IMW landscapes is dauntingly resource-intensive; de facto screening for salt tolerance by inferring from observable cues would add value to landscape architects, designers, and managers in selecting tolerant species for salt-affected landscapes. Conversely, such de facto screening could exclude species from wet, mesic habitats and with leaf traits as proxies of salt intolerance, e.g., riparian bigleaf maple and red maple (Acer rubrum; Hatter and Morgan, 1992). Similarly, ostensibly drought-tolerant species without definitive xeri-morphic leaf traits may have limited salt tolerance such as Cercis occidentalis (Niu et al., 2010) may be inferred to be less suitable for salt-affected landscapes. More explicit questions regarding how habitat and leaf traits link to salt tolerance could frame and add value to future screening for salt tolerance of landscape species.

\section{Literature Cited}

Abbruzzese, G., I. Beritognolo, R. Muleo, M. Piazzai, M. Sabatti, G.S. Mugnozza, and E. Kuzminsky. 2009. Leaf morphological plasticity and stomatal conductance in three Populus alba L. genotypes subjected to salt stress. Environ. Expt. Bot. 66:381-388.

Bartels, D. and R. Sunkar. 2005. Drought and salt tolerance in plants. Crit. Rev. Plant Sci. 24:2358.

Bsoul, E., R. St. Hilaire, and D.M. Vanleeuwen. 2007. Bigtooth maples from selected provenances effectively endure deficit irrigation. HortScience 42:1167-1173.

Bui, E.N. 2013. Soil salinity: A neglected factor in plant ecology and biogeography. J. Arid Environ. 92:14-25.

Carter, C.T. and C.M. Grieve. 2006. Salt tolerance of floriculture crops, p. 279-287. In: Khan, M.A. and D.J. Weber (eds.). Ecophysiology of high salinity tolerant plants. Springer Science + Business Media, Dordrecht, The Netherlands.

Cha-Um, S. and C. Kirdmanee. 2010. Effects of water stress induced by sodium chloride and mannitol on proline accumulation, photosynthetic abilities and growth characters of eucalyptus (Eucalyptus camaldulensis Dehnh.). New For. 40:349-360.

Cha-um, S. and C. Kirdmanee. 2012. Response of Eucalyptus camaldulensis Dehnh. to different salt affected soils. Acta Hort. 937:1057-1064.

Desmarais, Y. 1952. Dynamics of leaf variation in the sugar maples. Brittonia 7:347-387.

Farooq, S. and F.E. Azam. 2001. Co-existence of salt and drought tolerance in Triticeae. Hereditas 135:205-210.

Farrell, R.C.C., D.T. Bell, K. Akilan, and J.K. Marshall. 1996. Morphological and physiological comparisons of clonal lines of Eucalyptus camaldulensis. II. Responses to waterlogging/ salinity and alkalinity. Aust. J. Plant Physiol. 23:509-518.

Godman, R.M., W.H. Yawney, and C.H. Tubbs. 1990. Acer saccharum Marsh. sugar maple, p. 78-91. In: Burnsand, R.M. and B.H. Honkala (eds.). Silvics of North America. Vol. 2. Hardwoods. Agr. Hdbk. 654. U.S. Department of Agriculture, Forest Service, Washington, DC.

Grieve, C.M. 2011. Review irrigation of floricultural and nursery crops with saline wastewaters. Isr. J. Plant Sci. 59:187-196.

Grieve, C.M., M.R. Guzy, J.A. Poss, and M.C. Shannon. 1999. Screening Eucalyptus clones for salt tolerance. HortScience 34:867-870.

Grieve, C.M. and M.C. Shannon. 1999. Ion accumulation and distribution in shoot components of salt-stressed eucalyptus clones. J. Amer. Soc. Hort. Sci. 124:559-563.

Guttay, A.J.R. 1976. Impact of deicing salts upon the endomycorrhizae of roadside sugar maples. Soil Sci. Amer. J. 40:952-954.

Hatter, M.D. and D.L. Morgan. 1992. Growth and visual responses of three southwestern Acer taxa to high-salt irrigation water. J. Environ. Hort. 10:118-120.

Hawks, A., G. Cardon, and B. Black. 2009. Comparing strawberry salt tolerance using a low volume near-continuous gradient dosing system. J. Amer. Pomol. Soc. 63:136-141.

Huang, G., S. Ma, L. Bai, L. Zhang, H. Ma, P. Jia, J. Liu, M. Zhong, and Z. Guo. 2012. Signal transduction during cold, salt, and drought stresses in plants. Mol. Biol. Rep. 39:969987.

Jordan, L.A., D.A. Devitt, R.L. Morris, and D.S. Neuman. 2001. Foliar damage to ornamental trees sprinkler-irrigated with reuse water. Irrig. Sci. 21:17-25.
Kjelgren, R., L. Wang, and D. Joyce. 2009. Water deficit stress responses of three native Australian ornamental herbaceous wildflower species for water-wise landscapes. HortScience 44:13581365.

Maricle, B.R., D.R. Cobos, and C.S. Campbell. 2007. Biophysical and morphological leaf adaptations to drought and salinity in salt marsh grasses. Environ. Expt. Bot. 60:458-467.

McCulloh, K., J.S. Sperry, B. Lachenbruch, F.C. Meinzer, P.B. Reich, and S. Voelker. 2010 Moving water well: Comparing hydraulic efficiency in twigs and trunks of coniferous, ring-porous, and diffuse-porous saplings from temperate and tropical forests. New Phytol. 186:439-450.

Mee, W., J. Barnes, R. Kjelgren, R. Sutton, T. Cerny, and C. Johnson. 2003. Water wise: Native plants for Intermountain landscapes. Utah State Univ. Press, Logan, UT.

Meyer, S.E., R. Kjelgren, D. Morrison, and W.A. Varga. 2009. Landscaping on the new frontier: Waterwise design for the Intermountain West. Utah State Univ. Press, Logan, UT.

Mimura, T., M. Kura-Hotta, T. Tsujimura, M. Ohnishi, M. Miura, Y. Okazaki, M. Mimura, M. Maeshima, and S. Washitani-Nemoto. 2003. Rapid increase of vacuolar volume in response to salt stress. Planta 216:397-402.

Minore, D. and J.C. Zasada. 2010. Acer macrophyllum Pursh. USDA Forest Service, Northeastern Area Publications and Products. 4 Mar. 2014. <http://www.na.fs.fed.us/pubs/silvics manual/volume_2/acer/macrophyllum.htm $>$.

Munns, R. 2002. Comparative physiology of salt and water stress. Plant Cell Environ. 25:239250.

Munns, R. and M. Tester. 2008. Mechanisms of salinity tolerance. Annu. Rev. Plant Biol. 59:651-681.

Nasim, M., R.H. Qureshi, T. Aziz, M. Saqib, S. Nawaz, J. Akhtar, M.A. Haq, and S.T. Sahi. 2009. Different Eucalyptus species show different mechanisms of tolerance to salinity and salinity $\times$ hypoxia. J. Plant Nutr. 32:14271439.

Niu, G., D.S. Rodriguez, and M. Gu. 2010. Salinity tolerance of Sophora secundiflora and Cercis canadensis var. mexicana. HortScience 45: 424-427.

Niu, G.H. and R.I. Cabrera. 2010. Growth and physiological responses of landscape plants to saline water irrigation: A review. HortScience 45:1605-1609.

Pastori, G.M. and C.H. Foyer. 2002. Common components, networks, and pathway of crosstolerance to stress. The central role of redox and abscisic acid-mediated controls. Plant Physiol. 129:460-468.

Richards, M.R., L.A. Rupp, R. Kjelgren, and V.P. Rasmussen. 2012. Selection and budding propagation of native bigtooth maple for waterconserving landscapes. HortTechnology 22:669676.

Sarr, D.A., D.E. Hibbs, J.P.A. Shatford, and R. Momsen. 2011. Influences of life history, environmental gradients, and disturbance on riparian tree regeneration in Western Oregon. For. Ecol. Mgt. 261:1241-1253.

Schultz, H.R. 2003. Differences in hydraulic architecture account for near-isohydric and anisohydric behaviour of two field-grown Vitis vinifera $\mathrm{L}$. cultivars during drought. Plant Cell Environ. 26:1393-1405.

Shannon, M.C. 1997. Adaptation of plants to salinity. Adv. Agron. 60:75-120.

St. Hilaire, R., M.A. Arnold, D.C. Wilkerson, D.A Devitt, B.H. Hurd, B.J. Lesikar, V.I. Lohr, C.A. 
Martin, G.V. McDonald, R.L. Morris, D.R. Pittenger, D.A. Shaw, and D.F. Zoldoske. 2008. Efficient water use in residential urban landscapes. HortScience 43:2081-2092.

Tanji, K., S. Grattan, C. Grieve, A. Harivandi, L. Rollins, D. Shaw, B. Sheikh, and L. Wu. 2008. Salinity management guide. A comprehensive literature review on salt management guide for landscape irrigation with recycled water in coastal southern California. Salinity. 4 Mar. 2014. <http://www.salinitymanagement.org>.

Tardieu, F. and T. Simmoneau. 1998. Variability among species of stomatal control under fluctuating soil water status and evaporative demand:
Modelling isohydric and anisohydric behaviours. J. Expt. Bot. 49:419-432.

Valdez-Aguilar, L.A., C.M. Grieve, A. RazakMahar, M.E. McGiffen, and D.J. Merhaut. 2011. Growth and ion distribution is affected by irrigation with saline water in selected landscape species grown in two consecutive growing seasons: Spring-summer and fallwinter. HortScience 46:632-642.

White, D.A., N.C. Turner, and J.H. Galbraith 2000. Leaf water relations and stomatal behavior of four allopatric Eucalyptus species planted in Mediterranean southwestern Australia. Tree Physiol. 20:1157-1165.
Wright, I.J., M. Westoby, and P.B. Reich. 2002. Convergence towards higher leaf mass per area in dry and nutrient-poor habitats has different consequences for leaf life span. J. Ecol. 90:534-543.

Wu, L., X. Guo, and A. Harivandi. 2001. Salt tolerance and salt accumulation of landscape plants irrigated by sprinkler and drip irrigation systems. J. Plant Nutr. 24:1473-1490.

Zollinger, N., R. Koenig, T. Cerny-Koenig, and R. Kjelgren. 2007. Relative salinity tolerance of Intermountain Western United States native herbaceous perennials. HortScience 429:529 534. 